\title{
Comparison between Biochemical Analysis of Cattle Amniotic Fluid and Maternal Serum Components during Pregnancy
}

\author{
Walaa M. Essawi ${ }^{* 1}$, Doaa I.A. Mostafa ${ }^{2}$ and Amal I.A. El Shorbagy ${ }^{3}$ \\ ${ }^{1}$ Department of Theriogenology, Faculty of Veterinary Medicine, Aswan University, Egypt \\ ${ }^{2}$ Department of Clinical Pathology, Animal Health Research Institute, Zagazig branch, Sharkia, Egypt \\ ${ }^{3}$ Department of Chemistry, Toxicology and Nutritional Deficiency, Animal Health Research Institute, Zagazig Branch, Sharkia, Egypt \\ *Corresponding author's E-mail: walaamohamed1995@yahoo.com ; (DoRCiD: 0000-0002-3212-1400
}

\begin{abstract}
The present study aimed to compare the biochemical components including Total Protein (TP), albumin, globulins, cholesterol, triglycerides, High and Low-Density Lipoproteins (HDL and LDL), creatinine, urea, sodium (Na), potassium (K), chloride $(\mathrm{Cl})$, calcium $(\mathrm{Ca})$ and inorganic phosphorus $(\mathrm{P})$, of Amniotic Fluid (AF) with those of Maternal Serum (MS) during the first, second and third trimesters of pregnancy in cattle and Fetal Serum (FS) at birth. At birth AF, MS and FS were collected. Maternal blood samples and gravid uteri were collected after accidental slaughter. The actual data recorded during three trimesters according to the curved crown-anus length of the fetus. The MS concentrations of globulins, cholesterol, triglycerides, lipoproteins, creatinine, $\mathrm{Na}, \mathrm{K}, \mathrm{Cl}, \mathrm{Ca}$ and inorganic-P were significantly higher than the AF during the first trimester. At delivery, the concentrations of cholesterol, triglycerides, and creatinine in the AF were lower than those in the MS or FS. The concentrations of Ca and inorganic-P in the FS were higher than those in the MS or AF. The levels of TP, creatinine, urea in the AF and urea in the MS increased as the gestation stages advanced. The levels of $\mathrm{Na}$ and $\mathrm{Ca}$ in the $\mathrm{AF}$ decreased as the gestation stage advanced while the $\mathrm{K}$ concentration increased. In conclusion, our results indicated an active placental transport for $\mathrm{Ca}$ and $\mathrm{P}$. The TP, albumin, globulins, cholesterol, triglycerides, HDL and LDL, creatinine, urea, $\mathrm{Na}, \mathrm{K}, \mathrm{Cl}, \mathrm{Ca}$ and $\mathrm{P}$ in $\mathrm{AF}$ and $\mathrm{MS}$ during the first, second and third trimesters of pregnancy in cattle might be changed with progressing the gestation.
\end{abstract}

Keywords: Amniotic fluid, Cattle, Fetal serum, Gestation, Maternal blood

\section{INTRODUCTION}

The amnion formation occurs on days 13-14 of pregnancy in cattle, and then, the Amniotic Fluid (AF) fills the amniotic sac (Robert, 1986). Fetal membranes are extra-embryonic in nature (Minazaki et al., 2008). Amniotic fluid (AF), the protective liquid contained in the amniotic sac, is essential for fetal development and growth during gestation (Underwood et al., 2005, Fitzsimmons and Bajaj, 2019). AF is formed partly or entirely by the amnion, secretion from the respiratory tract, buccal cavity, nasal cavity, and embryonic skin before keratinization occurs (Moore 1982, Brace 1994, Hammer et al., 1997). AF accumulates early and subsequently diminishes as the embryo itself grows and this occurs in all species of mammals (Adolph, 1967). The fixed exchange of water and fluid component between the fetal compartments and the mother circulation by the fetoplacental unit shows the changes in the physical, chemical, and biochemical constituents of fetal fluids (Aidasani et al., 1993).

The fetal fluids are important for the handling of the fetal waste products and protect the fetus from the mechanical shock that has developed throughout pregnancy (Amle et al., 1992); they prevent adherence between fetal skin and the amniotic membrane (Williams et al., 1993); and during the expulsive stage they lubricated and widened the birth canal (Asbury and Blonc, 1993); they allow fetal development and movement inside the uterus (Zanella et al., 2014); and also inhibit bacterial and fungal growth (Zare-Bidaki et al., 2017). Biochemical analysis of AF is significantly important for the evaluation of fetal metabolism and pathological conditions during gestation (Prestes et al., 2001).

The purpose of the present study was to evaluate the biochemical components of AF in relation to maternal blood serum during the first, second and third trimesters in addition to those of Fetal Serum (FS) at birth to support our assumption. Cattle AF was a simple MS or FS dialysate, and the fetus played an important role in the final biochemical composition of the amniotic fluid during pregnancy. 


\section{MATERIAL AND METHODS}

\section{Ethical approval}

This experiment was conducted according to the rules of the Research Ethics Committee of the Veterinary faculty of Aswan University in Egypt.

\section{Sampling}

A field survey planned on using data collected from different abattoirs located in Darwa, Aswan, Egypt during the period between 2018 and 2019. Maternal serum and amniotic fluid were harvested from 40 emergency slaughtered animals at different stages of gestation. The age of these animals varied from 2 and 12 years old and the breeding history was unknown. 20 animals were enrolled during normal labor.

\section{Maternal serum}

Maternal blood samples were obtained via jugular venipuncture and collected in sterile glass tubes. The blood samples were allowed to clot, and centrifuged at 3000 round per minute (rpm) for 15 minutes; the serum was separated and stored at $20^{\circ} \mathrm{C}$ for further analysis.

\section{Amniotic fluid}

The gravid uteri were removed immediately after slaughter to collect the AF. The gravid uteri were incised through greater curvature with a sharp scalpel to locate the fetal sacs, and then carefully separated from the endometrium and slowly enclosed outside the horn. The AF was collected by puncturing the amniotic sac and $10 \mathrm{ml}$ of AF was aspirated from the amniotic sac using $10 \mathrm{ml}$ disposable syringes, or amniotic fluid samples were obtained transcervically during delivery. The aspirated fluid was stored in labelled tubes and frozen at $-20^{\circ} \mathrm{C}$ until biochemical analysis.

\section{Fetal serum}

Fetal blood was obtained from the umbilical vessels. The blood samples were allowed to clot, and centrifuged at $3000 \mathrm{rpm}$ for 15 minute; the serum was separated and stored at $-20^{\circ} \mathrm{C}$ for further analysis.

\section{Fetal age and detection of the gestation period}

The fetuses were expelled from enclosing membranes and the fetal ages were determined by applying the age estimation formula, $X=2.5(y+21)$, presented by Richardson et al. (1990), where X equaled to developmental age in days and y was the crown-anus length in centimeters. The cattle presented different stages of pregnancy and were divided into first, second and third trimesters of pregnancy.

\section{Biochemical studies}

Serum urea and creatinine levels were determined calorimetrically using diagnostic kits according to Tietz et al. (1995). The serum Ca level was determined according to Connell (2012). The inorganic phosphorus (inorganic P) level in the serum content was determined according to Berti et al. (1988). The Na and potassium (K) levels in the serum were estimated with a flame-photometer according to Bauer (1982) and serum chloride (Cl) level was determined according to Chirife and Resnik (1984). The Total Protein (TP) content was determined according to Henry et al. (1974). Albumin content was determined according to Doumas and Biggs (1972). The serum globulin level was calculated by subtracting the albumin level obtained from the TP content. Immunoglobulin electrophoresis was performed as described by Henry et al. (1974). The total serum cholesterol was measured according to Mamoru et al. (1977). The serum triglyceride concentrations were measured according to Izzo et al. (1981). The serum High-Density Lipoprotein Cholesterol (HDLC) and Low-Density Lipoprotein Cholesterol (LDL-C) levels were estimated according to Nauck et al. (2002) and Friedewald et al. (1972) respectively.

\section{Statistical analysis}

The data obtained were statistically analyzed by F-test according to Tamhane and Dunlop (2000) using the computer program MSTAT-C. Means values in the same row with different letters are statistically significant and the highest values are represented with the letter (a). Statistical significance was declared at the $\mathrm{p} \leq 0.05$ level and the data are presented as the mean $\pm \mathrm{SE}$.

\section{RESULTS}

The TP, albumin, globulin, $\alpha_{1}$ globulin, $\alpha_{2}$ globulin, $\beta$ globulin, $\gamma$ globulin, cholesterol, triglycerides, HDL, LDL, some metabolites such as urea and creatinine, monovalent cations $(\mathrm{Na}$ and $\mathrm{K})$ and monovalent anion $(\mathrm{Cl})$, as well as $\mathrm{Ca}$ and phosphorus levels of the MS and AF are given in tables 1 and 2. 
Table 1. Lipids and proteins levels in amniotic fluid and maternal serum of pregnant cattle slaughtered in Darwa and Aswan abattoirs, of Egypt during first, second and third trimesters of gestation.

\begin{tabular}{|c|c|c|c|c|}
\hline \multirow{2}{*}{ Parameter } & \multirow{2}{*}{ Type of fluid } & \multicolumn{3}{|c|}{ Trimester } \\
\hline & & First $(n=20)$ & Second $(n=10)$ & Third $(n=10)$ \\
\hline \multirow{2}{*}{ Total proteins, $(\mathrm{g} / \mathrm{dl})$} & Amniotic fluid & $4.37 \pm 0.08^{b}$ & $6.16 \pm 0.56^{\mathrm{a}}$ & $6.44 \pm 0.39^{\mathrm{a}}$ \\
\hline & Maternal serum & $4.66 \pm 0.35^{\mathrm{b}}$ & $5.80 \pm 0.44^{\mathrm{a}}$ & $5.81 \pm 0.46^{\mathrm{a}}$ \\
\hline \multirow{2}{*}{ Albumin, (g/dl) } & Amniotic fluid & $3.1 \pm 0.07^{\mathrm{b}}$ & $4.26 \pm 0.28^{\mathrm{a}}$ & $4.48 \pm 0.31^{\mathrm{a}}$ \\
\hline & Maternal serum & $2.33 \pm 0.06^{\mathrm{c}}$ & $3.59 \pm 0.3^{\mathrm{a}}$ & $3.6 \pm 0.81^{\mathrm{a}}$ \\
\hline \multirow{2}{*}{ Globulin, (g/dl) } & Amniotic fluid & $1.27 \pm 0.02^{\mathrm{c}}$ & $1.9 \pm 0.23^{b}$ & $1.96 \pm 0.32^{\mathrm{b}}$ \\
\hline & Maternal serum & $2.33 \pm 0.3^{\mathrm{a}}$ & $2.21 \pm 0.15^{\mathrm{a}}$ & $2.2 \pm 0.17^{\mathrm{a}}$ \\
\hline \multirow{2}{*}{$\alpha 1$ globulin, $(\mathrm{g} / \mathrm{dl})$} & Amniotic fluid & $0.13 \pm 0.01^{\mathrm{c}}$ & $0.22 \pm 0.009^{\mathrm{ab}}$ & $0.14 \pm 0.006^{\mathrm{c}}$ \\
\hline & Maternal serum & $0.25 \pm 0.03^{\mathrm{a}}$ & $0.20 \pm 0.009^{\mathrm{b}}$ & $0.18 \pm 0.003^{\mathrm{bc}}$ \\
\hline \multirow{2}{*}{$\alpha 2$ globulin,(mg/dl) } & Amniotic fluid & $0.28 \pm 0.03^{\mathrm{c}}$ & $0.22 \pm 0.08^{\mathrm{c}}$ & $0.32 \pm 0.02^{\mathrm{c}}$ \\
\hline & Maternal serum & $1.45 \pm 0.19^{\mathrm{a}}$ & $1.17 \pm 0.009^{\mathrm{a}}$ & $0.87 \pm 0.06^{\mathrm{b}}$ \\
\hline \multirow{2}{*}{$\beta$ globulin, $(\mathrm{g} / \mathrm{dl})$} & Amniotic fluid & $0.42 \pm 0.04^{\mathrm{d}}$ & $1.89 \pm 0.18^{b}$ & $0.45 \pm 0.029^{\mathrm{d}}$ \\
\hline & Maternal serum & $2.9 \pm 0.44^{\mathrm{a}}$ & $1.6 \pm 0.057^{\mathrm{bc}}$ & $1.11 \pm 0.015^{\mathrm{c}}$ \\
\hline \multirow[b]{2}{*}{$\gamma$ globulin, $(\mathrm{g} / \mathrm{dl})$} & Amniotic fluid & $0.42 \pm 0.03^{\mathrm{e}}$ & $1.84 \pm 0.12^{\mathrm{c}}$ & $0.55 \pm 0.06^{\mathrm{e}}$ \\
\hline & Maternal serum & $2.71 \pm 0.12^{\mathrm{a}}$ & $2.12 \pm 0.06^{\mathrm{b}}$ & $1.68 \pm 0.08^{\mathrm{d}}$ \\
\hline \multirow{2}{*}{ Cholesterol,(mg/dl) } & Amniotic fluid & $17.32 \pm 0.56^{\mathrm{d}}$ & $16.93 \pm 0.97^{\mathrm{d}}$ & $16.08 \pm 0.79^{d}$ \\
\hline & Maternal serum & $182 \pm 6.47^{\mathrm{a}}$ & $136 \pm 2.7^{\mathrm{b}}$ & $124.57 \pm 5.85^{\mathrm{c}}$ \\
\hline \multirow{2}{*}{ Triglycerides,(mg/dl) } & Amniotic fluid & $20.41 \pm 3.22^{\mathrm{c}}$ & $22.3 \pm 4.3^{\mathrm{c}}$ & $18.7 \pm 0.91^{\mathrm{c}}$ \\
\hline & Maternal serum & $103.34 \pm 4.1^{\mathrm{a}}$ & $95.83 \pm 1.09^{\mathrm{a}}$ & $77.2 \pm 6.1^{\mathrm{b}}$ \\
\hline \multirow{2}{*}{ HDL, (mg/dl) } & Amniotic fluid & $28.1 \pm 2.7^{b}$ & $25.38 \pm 2.07^{b}$ & $21.42 \pm 0.6^{b}$ \\
\hline & Maternal serum & $49.24 \pm 2.17^{\mathrm{a}}$ & $47.17 \pm 1.92^{\mathrm{a}}$ & $43.72 \pm 2.18^{\mathrm{a}}$ \\
\hline \multirow{2}{*}{$\mathrm{LDL},(\mathrm{mg} / \mathrm{dl})$} & Amniotic fluid & $5.67 \pm 0.23^{\mathrm{d}}$ & $5.24 \pm 0.42^{\mathrm{d}}$ & $5.13 \pm 0.5^{\mathrm{d}}$ \\
\hline & Maternal serum & $54.4 \pm 1.69^{c}$ & $62.33 \pm 2.85^{\mathrm{b}}$ & $69.67 \pm 0.96^{\mathrm{a}}$ \\
\hline
\end{tabular}

Data are expressed as mean values \pm Standard error; the number of studied samples in each trimester of gestation are shown in parentheses. Values with different superscripts are significantly different at $\mathrm{p} \leq 0.05 . \mathrm{n}=$ the number of studied samples, HDL $=$ High Density Lipoprotein, LDL $=$ Low Density Lipoprotein

Table 2. The levels of metabolites and ions in amniotic fluid and maternal serum during first, second and third trimesters of gestation in cattle slaughtered in Darwa and Aswan abattoirs of Egypt.

\begin{tabular}{|c|c|c|c|c|}
\hline \multirow{2}{*}{ Parameters } & \multirow{2}{*}{ Type of fluid } & \multicolumn{3}{|c|}{ Trimesters } \\
\hline & & First $(n=20)$ & Second $(n=20)$ & Third $(n=20)$ \\
\hline \multirow{2}{*}{ Creatinine (mg/dl } & Amniotic fluid & $1.06 \pm 0.17^{\mathrm{b}}$ & $1.26 \pm 0.13^{\mathrm{ab}}$ & $1.62 \pm 0.14^{\mathrm{a}}$ \\
\hline & Maternal serum & $1.63 \pm 0.4^{\mathrm{a}}$ & $1.70 \pm 0.05^{\mathrm{a}}$ & $1.77 \pm 0.06^{\mathrm{a}}$ \\
\hline \multirow{2}{*}{ Urea (mg/dl) } & Amniotic fluid & $22.87 \pm 1.27^{\mathrm{C}}$ & $24.37 \pm 2.01^{\mathrm{c}}$ & $26.3 \pm 2.06^{\mathrm{ab}}$ \\
\hline & Maternal serum & $24.11 \pm 0.58^{c}$ & $27 \pm 1.5^{\mathrm{ab}}$ & $28.37 \pm 1.68^{\mathrm{a}}$ \\
\hline \multirow{2}{*}{ Sodium $(\mathrm{mEq} / \mathrm{L})$} & Amniotic fluid & $111.36 \pm 1.43^{\mathrm{b}}$ & $107.3 \pm 3.7^{\mathrm{b}}$ & $86.2 \pm 5.47^{\mathrm{c}}$ \\
\hline & Maternal serum & $135.8 \pm 1.9^{\mathrm{a}}$ & $133.27 \pm 0.93^{\mathrm{a}}$ & $131.33 \pm 4.67^{\mathrm{a}}$ \\
\hline \multirow{2}{*}{ Potassium (mEq/L) } & Amniotic fluid & $1.76 \pm 0.29^{c}$ & $2.06 \pm 0.17^{\mathrm{c}}$ & $2.7 \pm 0.06^{\mathrm{b}}$ \\
\hline & Maternal serum & $3.84 \pm 0.12^{\mathrm{a}}$ & $3.5 \pm 0.06^{\mathrm{a}}$ & $3.57 \pm 0.22^{\mathrm{a}}$ \\
\hline \multirow{2}{*}{ Chloride (mEq/L) } & Amniotic fluid & $78.55 \pm 2.45^{\mathrm{b}}$ & $80.29 \pm 0.09^{b}$ & $83.2 \pm 0.97^{\mathrm{b}}$ \\
\hline & Maternal serum & $95.81 \pm 0.79^{\mathrm{a}}$ & $94.27 \pm 0.38^{\mathrm{a}}$ & $93.33 \pm 0.88^{\mathrm{a}}$ \\
\hline \multirow{2}{*}{ Calcium (mg/dl) } & Amniotic fluid & $7.23 \pm 0.3^{\mathrm{b}}$ & $6.69 \pm 0.22^{\mathrm{b}}$ & $6.13 \pm 0.23^{\mathrm{c}}$ \\
\hline & Maternal serum & $9.22 \pm 0.71^{\mathrm{a}}$ & $9.24 \pm 0.15^{\mathrm{a}}$ & $8.82 \pm 0.18^{\mathrm{a}}$ \\
\hline \multirow{2}{*}{ Inorganic phosphorus(mg/dl) } & Amniotic fluid & $3.22 \pm 0.21^{\mathrm{b}}$ & $3.9 \pm 0.19^{\mathrm{ab}}$ & $4.04 \pm 0.09^{\mathrm{ab}}$ \\
\hline & Maternal serum & $5.16 \pm 0.08^{\mathrm{a}}$ & $5.05 \pm 0.11^{\mathrm{a}}$ & $4.77 \pm 0.14^{\mathrm{a}}$ \\
\hline
\end{tabular}

Data are expressed as mean values \pm Standard error; the number of studied samples in each trimester of gestation is shown in parentheses. Values with different superscripts are significantly different at $\mathrm{p} \leq 0.05 . n=$ the number of studied samples

\section{Proteinogram}

The AF proteinogram showed a significant $(\mathrm{p} \leq 0.05)$ increase in TP content in the $2^{\text {nd }}$ and $3^{\text {rd }}$ trimesters compared to the MS. The TP, $\alpha_{2}$ globulin and $\gamma$ globulin levels increased as the gestation increased. The MS TP content was not significantly higher than the AF TP content during the first trimester. The albumin level increased significantly in the first trimesters in the AF compared to the MS. The globulin, $\alpha_{1}$ globulin, $\alpha_{2}$ globulin, $\beta$ globulin and $\gamma$ globulin levels were significantly lower in the AF than in the MS.

\section{Cholesterol, triglycerides, HDL and LDL}

The cholesterol, triglycerides, HDL and LDL levels in the AF were not significantly different among the three trimesters of gestation but remained low compared to those in the MS throughout the pregnancy. The mean cholesterol, triglycerides, and HDL values in the MS were decreased significantly $(\mathrm{p} \leq 0.05)$ as the gestation stage advanced, but the LDL level increased with gestation progressed. 


\section{Creatinine}

The AF creatinine increased with gestation stage. The AF creatinine level was lower than the MS creatinine level in the $1^{\text {st }}$ trimester. The MS creatinine level did not change significantly $(\mathrm{p} \leq 0.05)$ throughout the pregnancy.

\section{Urea}

The concentration of urea in the AF gradually increased during gestation. The urea concentration in the AF was significantly lower than that in the MS in the $2^{\text {nd }}$ trimester of gestation.

\section{Sodium (Na)}

The AF Na concentration decreased significantly $(p \leq 0.05)$ as the pregnancy progressed and was lower than that in the MS, but the MS Na concentration did not change significantly during pregnancy.

\section{Potassium (K)}

The AF K level increased significantly $(\mathrm{p} \leq 0.05)$ with increasing the gestational stage and remained in lower concentrations than the MS K levels. However, the MS K levels did not differ significantly $(p \leq 0.05)$ during the three trimesters of pregnancy.

\section{Chloride (Cl)}

The concentrations of $\mathrm{Cl}$ were significantly higher in $\mathrm{MS}$ than in the AF.

\section{Calcium (Ca)}

The AF showed a significant $(\mathrm{p} \leq 0.05)$ decrease in Ca concentration as the gestation stage advanced while there was no significant difference in Ca levels in the MS. The AF Ca levels were consistently lower than the MS Ca levels throughout the pregnancy.

\section{Inorganic $\mathbf{P}$}

The concentrations of inorganic Pin the AF increased insignificantly $(p \leq 0.05)$ as the pregnancy progressed. The MS inorganic P level did not change significantly throughout the pregnancy. At delivery state, the levels of all the examined biochemical components were determined simultaneously in the AF, MS and FS samples (Table 3). The mean concentrations of TP, albumin and globulin in the matched samples were insignificantly $(\mathrm{p} \leq 0.05)$ different among the $\mathrm{AF}$, MS and FS, but the $\alpha_{1}$ globulin, $\alpha_{2}$ globulin, $\beta$ globulin and $\gamma$ globulin levels in AF were significantly $(\mathrm{p} \leq 0.05)$ lower than those in the MS or FS. The concentrations of cholesterol and triglycerides were significantly $(\mathrm{p} \leq 0.05)$ lower in the AF than in the MS or FS. The creatinine level in the AF was significantly lower than that in the MS and FS. The urea level was not significantly different in the matching samples; amniotic fluid (AF) and maternal serum (MS) samples collected during three trimesters of gestation in cattle. The concentrations of $\mathrm{Na}, \mathrm{K}$ and $\mathrm{Cl}$ in the $\mathrm{AF}$ were not significantly higher than those in the MS and FS, and concentrations of other electrolytes including Ca and inorganic $\mathrm{P}$ were significantly lower in the AF and the MS than in the FS.

Table3. The levels of biochemical components in amniotic fluid, maternal serum and fetal serum at birth time of cattles slaughtered in Darwa and Aswan abattoirs of Egypt

\begin{tabular}{|c|c|c|c|}
\hline Parameter & $\begin{array}{c}\text { Amniotic fluid } \\
(\mathbf{n}=20)\end{array}$ & $\begin{array}{l}\text { Maternal serum } \\
\quad(\mathrm{n}=20)\end{array}$ & $\begin{array}{c}\text { Fetal serum } \\
(\mathbf{n}=\mathbf{2 0})\end{array}$ \\
\hline Total proteins $(\mathrm{g} / \mathrm{dl})$ & $6.64 \pm 0.21$ & $7.22 \pm 0.94$ & $6.15 \pm 0.43$ \\
\hline Albumin (g/dl) & $4.37 \pm 0.41$ & $4.91 \pm 0.23$ & $4.17 \pm 0.17$ \\
\hline Globulin (g/dl) & $2.27 \pm 0.14$ & $2.31 \pm 0.31$ & $1.98 \pm 0.31$ \\
\hline$\alpha 1$ globulin $(\mathrm{g} / \mathrm{dl})$ & $0.05 \pm 0.02^{\mathrm{c}}$ & $0.19 \pm 0.003^{\mathrm{b}}$ & $0.21 \pm 0.02^{\mathrm{a}}$ \\
\hline$\alpha 2$ globulin $(\mathrm{g} / \mathrm{dl}$ & $0.093 \pm 0.04^{\mathrm{c}}$ & $1.22 \pm 0.07^{\mathrm{a}}$ & $1.17 \pm 0.12^{\mathrm{b}}$ \\
\hline$\beta$ globulin (g/dl) & $0.17 \pm 0.07^{\mathrm{c}}$ & $1.5 \pm 0.057^{\mathrm{a}}$ & $1.81 \pm 0.23^{\mathrm{a}}$ \\
\hline$\gamma$ globulin $(\mathrm{g} / \mathrm{dl})$ & $0.22 \pm 0.08^{\mathrm{c}}$ & $1.99 \pm 0.05^{\mathrm{a}}$ & $1.02 \pm 0.12^{\mathrm{b}}$ \\
\hline Cholesterol (mg/dl) & $15.67 \pm 0.67^{\mathrm{c}}$ & $103.5 \pm 4.8^{\mathrm{a}}$ & $85.87 \pm 4.5^{\mathrm{b}}$ \\
\hline Triglycerides (mg/dl) & $18.32 \pm 2.67^{\mathrm{b}}$ & $76.05 \pm 4.8^{\mathrm{a}}$ & $75.57 \pm 4.27^{\mathrm{a}}$ \\
\hline $\mathrm{HDL}(\mathrm{mg} / \mathrm{dl})$ & $10.43 \pm 0.29^{\mathrm{b}}$ & $42.17 \pm 2.35^{\mathrm{a}}$ & $39.62 \pm 5.32^{\mathrm{a}}$ \\
\hline $\mathrm{LDL}(\mathrm{mg} / \mathrm{dl})$ & $5.82 \pm 0.23^{\mathrm{c}}$ & $73.67 \pm 2.9^{\mathrm{a}}$ & $34.39 \pm 2.49^{b}$ \\
\hline Creatinine (mg/dl) & $1.75 \pm 0.11^{\mathrm{b}}$ & $1.85 \pm 0.07^{\mathrm{ab}}$ & $2.27 \pm 0.28^{\mathrm{a}}$ \\
\hline Urea (mg/dl) & $26.96 \pm 2.28$ & $28.47 \pm 2.3$ & $29.83 \pm 2.08$ \\
\hline Sodium $(\mathrm{mEq} / \mathrm{L})$ & $125 \pm 1.53$ & $121.7 \pm 4.36$ & $117.00 \pm 2.31$ \\
\hline Potassium (mEq/L) & $2.99 \pm 0.05$ & $2.85 \pm 0.12$ & $2.8 \pm 0.02$ \\
\hline Chloride (mg/dl) & $91.12 \pm 0.68$ & $89.09 \pm 1.37$ & $88.29 \pm 0.41$ \\
\hline Calcium (mg/dl) & $8.43 \pm 0.22^{\mathrm{b}}$ & $8.77 \pm 0.14^{\mathrm{b}}$ & $10.54 \pm 0.25^{\mathrm{a}}$ \\
\hline Inorganic phosphorus (mg/dl) & $4.64 \pm 0.32^{\mathrm{b}}$ & $4.38 \pm 0.17^{\mathrm{b}}$ & $7.35 \pm 0.11^{\mathrm{a}}$ \\
\hline
\end{tabular}

Data are expressed as mean values \pm Standard error; rows with different letters $(a, b, c)$ are significantly different at $p \leq 0.05$. The number of studied samples is shown in parentheses. $\mathrm{n}=$ the number of studied samples, HDL= High Density Lipoprotein, $\mathrm{LDL}=$ Low Density Lipoprotein. 
The developing fetus is surrounded by AF. The AF volume and composition are affected by fetal urination, drinking and fetal membrane permeability. Hormones such as prolactin and cortisol, may play an important role by affecting membrane permeability (Wintour et al., 1986).

The Na concentrations in the AF decreased in the three trimesters studied compared to those in the MS. In ovine, a similar result was recorded by Prestes et al. (2001) who found that the minerals act on fetal kidneys, increasing the K and decreasing the $\mathrm{Na}$ concentration in fetal urine. At the end of pregnancy, the fetal kidney reabsorbed $85 \%$ to $95 \%$ of $\mathrm{Na}$ ion from the filtrate load. So, the hypo-tonicity of fetal urine compared to plasma, indicating the efficacy of the collecting duct (Robillard et al., 1988). The results of the present study were concurred with high Na reabsorption of and a relatively low AF concentration in the third trimester of gestation, as mentioned by Brenner (1990). According to Wintour et al. (1986) a classic Na pump could be responsible and the alteration in the relative permeability for Na and $\mathrm{K}$ might affect the transport. The $\mathrm{K}$ content increased in the AF as gestation progressed. These results incompetence with the maturation of distal and collecting tubules, that are responsible for K regulation by the fetal kidney (Satlin, 1991), confirming observations reported by Benzie et al. (1974). There was an insignificant decrease in $\mathrm{Cl}$ concentration as pregnancy progressed, and the concentration was significantly lower in the AF than in the MS. According to Mellor and Slatter (1971), fetal orosomucoid secretion could be a source of $\mathrm{Cl}$ (found in the AF).

The Ca content in the AF decreased as gestation advanced. This was contrariwise for the phosphorus content in AF. $\mathrm{Ca}$ and phosphorus are important for the development of the fetal skeleton. Thus, it would be expected that the fetus excreted very little into the AF when preserving these elements. Wales and Murdoch (1973) reported that the Ca concentration in the ovine fetus AF decreased very slightly between $31^{\text {st }}$ and $44^{\text {th }}$ day of pregnancy.

At delivery, there were no available references to compare the results of the present study with it. Comparing the biochemical components and electrolytes levels in AF, MS and FS in the cattle, had been found that first the levels of organic substances in the AF, including TP, cholesterol, and triglycerides were lower than in MS and FS; second insignificant change in the concentrations of metabolites including urea and creatinine in the AF and MS or FS except significant increase in the FS urea than in the AF, and third the levels of $\mathrm{Na}, \mathrm{K}$ and $\mathrm{Cl}$ in the $\mathrm{AF}$ were almost the same as in the MS and FS and the levels of Ca and P in the FS were significantly higher than those in the AF and MS. These data suggested that the electrolytes in the AF might be derived from MS but the fetus was the main source of other organic components and metabolites present in the AF. The present study revealed that the Ca and P levels in fetal serum were higher than in MS, which could be caused by active transport of $\mathrm{Ca}$ and $\mathrm{P}$ from pregnant cattle to the fetus through the placenta and increased absorption in the fetus. The presence of metabolites, including urea and creatinine in the AF, represented the excretion of urine from the fetus (Anderer and Schinder, 1975). The content of TP in the AF and FS were similar in the present study, which could suggest that AF played a role in fetal development and that both electrolytes and proteins found in the AF were required to balance the osmotic pressure between AF and blood, as reported by Tong et al. (2009).

\section{CONCLUSION}

Cattle AF was a simple MS or FS dialysate, and the fetus played an important role in the final biochemical composition of the amniotic fluid during pregnancy. The concentration of cholesterol, triglycerides, TP, creatinine, urea, $\mathrm{Na}, \mathrm{K}, \mathrm{Cl}$, $\mathrm{Ca}$ and $\mathrm{P}$ in cattle AF and MS might change as the pregnancy progressed. Studying the changes in the biochemical composition of the AF during the development of pregnancy was of great value, because it explained the mechanisms of AF formation and determined the physiological function of AF during the development of the fetus. In addition, this knowledge was of utmost importance in order to understanding fetal metabolism and pregnancy associated abnormalities. Further research is needed to better correlate changes in the AF biochemical composition changes with fetal organ development and maturation, and to investigate pregnancy-associated abnormalities.

\section{DECLARATION}

\section{Competing interests}

The authors declare that there is no conflict of interest in the present work. This research did not receive any specific grant from funding agencies in the public, commercial, or not-for-profit sector.The protocol was approved accordance with National Regulations on Institutional Animal Care and Use Ethical Committee and animal welfare.

\section{Consent to publish}

All authors have given their consent before entering the study. 


\section{Authors' contributions}

Walaa M. Essawi detected the stage of pregnancy, collected the samples and participated in the preparation of the manuscript, Doaa I.A. Mostafa and Amal I.A. El Shorbagy performed the biochemical investigations, data analysis and prepared the manuscript (writing and revision). All authors approved the final version of manuscript before publication.

\section{REFERENCES}

Adolph E (1967). Ontogeny of volume regulations in embryonic extracellular fluids. The Quarterly review of biology, 42 (1): 1-39. Available at: https://www.journals.uchicago.edu/doi/abs/10.1086/405244.

Aidasani R, Chauhan R, Tiwari S and Shukla S (1993). Studies on electrolytes of caprine foetal fluid and foetal serum. Indian Veterinary Journal, Available at: http://agris.fao.org/agris-search/search.do?recordID=IN19930068073.

Aidasani R, Pieterse M, Derweyden GV and Taverine M (1992). Some metabolic constituents of caprine fetal fluids and fetal serum. Indian Journal of Animal Science, 62: 335-336. Available at: http://epubs.icar.org.in/ejournal/index.php/IJAnS/index.

Amle M, Chinchkar S, Hukeri V and Deopurkor V (1992). Studies on fetal fluids of buffaloes. Indian Journal of Animal Reproduction, 13: 165-167. Available at: http://www.journals4free.com/link.jsp?l=928357.

Anderer M and Schinder A (1975). Creatinine, urea and uric acid in amniotic fluid, maternal and umbilical cord blood at delivery. Archiv für Gynäkologie, 220: 65-72. Available at: https://link.springer.com/article/10.1007/BF00673149.

Anitha A and Thangavel A (2011). Biochemical profile of ovine amniotic and allantoic fluids. Tamilnadu Journal Veterinary And Animal Sciences, 7: 262-267. Available at: http://www.tanuvas.ac.in/tnjvas/tnjvas/vol7(6)/262_267.

Asbury A and Blonc ML (1993). The placenta. In: Mckinnon AO Voss JL, editors. Equine reproduction. Philadelphia: lea and febiger; p. 509-516. Available at: https://www.worldcat.org/title/equine-reproduction/oclc/24247046.

Bauer J (1982). Chemical laboratory methods. 9th Edition. London: The CM Mosby Company; Available at: https://www.amazon.com/Clinicallaboratory-methods-John-Bauer/dp/0801605083.

Benzie R, Doron T, Harki J, Owen VJ and Porter C (1974). Composition of the amniotic fluid and maternal serum in pregnancy. American Journal of Obstetrics and Gynecology, 119: 798-810. Available at: https://www.sciencedirect.com/science/article/abs/pii/0002937874900933.

Berti G, Fossati P, Tarenghi G, Musitelli C and d'Eril GM (1988). Enzymatic colorimetric method for the determination of inorganic phosphorus in serum and urine. 26 (6): 399-404. Available at: Journal of. Clinical Chemistry and Clinical Biochemistry, Available at: https://www.degruyter.com/view/j/cclm.1988.26.issue-6/cclm.1988.26.6.399/cclm.1988.26.6.399.

Brace R (1994). Foetal fluid balance. In: Thorburn GD HR, editors., editor. TextBook of fetal physiology. New York: Oxford University Press; p. 205218. Available at: https://academic.oup.com/biolreprod/article/73/1/139/2667232.

Brenner B (1990). Determination of differentiation during early nephrogenesis. Journal of the american society of nephrology, 1: 127-130. Available at: https://jasn.asnjournals.org/content/1/2/127.

Brzenzinski A, Sadovsky E and Shafrir E (1964). Protein composition of early amniotic fluid and foetal serum with a case of dis-albumineamia. American Journal of Obstetrics and Gynecology, At: https://www.sciencedirect.com/science/article/abs/pii/0002937864905538.

Chez R, Smith J and Hutchinson D (1964). Renal function in the intrauterine primate fetus. I.Experimental technique; rate of formation and chemical composition of urine. American Journal of Obstetrics and Gynecology, 90: 128. Available at: https://www.ajog.org/article/S00029378(16)34900-6.

Chirife J and Resnik SL (1984). Unsaturate solution of sodium chloride as reference sources of water activity at various temperatures. Journal of Food Science, 49 (6): 1486-14. DOI: https://org/10.1111/j.1365-2621.1984.tb12827.x88.

Connell E (2012). Tietz textbook of clinical chemistry and molecular diagnostics. 5th edition. SAGE Publications Sage UK: London, England. DOI: https://org/10.1258/acb.2012.201217.

Cruikshank DP (1982). Amniocentesis for determination of fetal maturity. Clinical Obstetrics and Gynecology, 25: 773-785. Available at: https://journals.lww.com/clinicalobgyn/Citation/1982/12000.

Doumas B and Biggs H (1972). Standard methods of clinical chemistry. New York: Academic Press; New York,7: 175-188. Available at: https://www.scirp.org/(S(lz5mqp453edsnp55rrgjct55))/reference/ReferencesPapers.aspx?ReferenceID=28112.

Fitzsimmons ED and Bajaj T (2019). Embryology, amniotic fluid. StatPearls Publishing; p.1-4 Available at: https://www.ncbi.nlm.nih.gov/books/NBK541089.

Fresno L, Rodriguez-Gil J, Rigua J, Pastor J and Alamo MRD (2012). Modulation of the biochemical composition of amniotic and allantoic fluids as a control mechanism of feline foetal development. Placenta, 33: 522-527. Available at: https://www.sciencedirect.com/science/article/abs/pii/S0143400412001099.

Friedewald W, Levy R and Fredrickson D (1972). Estimation of the concentration of low-density lipoprotein cholesterol in plasma, without use of the preparative ultracentrifuge. Clinical chemistry, 18: 499-502. Available at: https://academic.oup.com/clinchem/article/18/6/499/5676160

Gulbis B, Gervy C and Jauniaux E (1998). Amniotic fluid biochemistry in second-trimester trisomic pregnancies relationships to fetal organ maturation and dysfunction. Early Human Development, https://www.sciencedirect.com/science/article/abs/pii/S0378378298000231

Hammer A, Hutter H, Blaschits A, Mahnert W, Hartmann M, Uchanska-Ziegler B, Ziegler A and Dohr G (1997). Amnion epithelial cells, in contrast to trophoblast cells, express all classical hla class i molecules together with hla-g. American Journal of Reproductive Immunology, 37: 161-171. Available at: https://onlinelibrary.wiley.com/doi/abs/10.1111/j.1600-0897.1997.tb00208.

Henry RJ, Canin DC and Winkelman JW (1974). Clinical chemistry. Principle and techniques. $2^{\text {nd }}$ Edition. Harper and Row;New York,pp1196. Available at: http://www.sciepub.com/reference/111332.

Izzo C, Grillo F and Murador E (1981). Improved method for determination of high-density-lipoprotein cholesterol i. Isolation of high-density lipoproteins by use of polyethylene glycol 6000. Clinical chemistry, 27: 371-374. Available at: https://academic.oup.com/clinchem/article/27/3/371/5666528.

Khadjeh G, Ranjbar R, Salehi M and Banankhojasteh S (2007). Biochemical evaluation of amniotic during different stages of gestation in the goat, IRANIAN JOURNAL OF VETERINARY RESEARCH. 8: 266-269. Available at: https://www.sid.ir/en/Journal/ViewPaper.aspx?ID=85265.

Khatun A, Wani G, Bhat J, Choudhury A and Khan M (2011). Biochemical indices in sheep during different stages of pregnancy. Asian Journal of animal and veterinary advances, 6 (2): 175-181. Available at: http://docsdrive.com/pdfs/academicjournals/ajava/2011/175-181.

Lind T, Billewic W and Chene G (1971). Composition of amniotic fluid and maternal blood through pregnancy. An international journal of obstetrics and gynaecology, 78: 505-512. Available at: https://obgyn.onlinelibrary.wiley.com/doi/abs/10.1111/j.1471-0528.1971.tb00308. 
Lovell K, Sprecher D, Ames N and Jones M (1995). Development and efficacy of ultrasound-guided fetal fluid aspiration techniques for prenatal diagnosis of caprine $\quad \beta$-mannosidosis. $\quad$ Theriogenology, $\quad 44: \quad 517-527 . \quad$ Available https://www.sciencedirect.com/science/article/abs/pii/0093691X9500223.

Mamoru S, Tsutomu O, Kazuyuki H, Hidemi M, S Hiroko Y, Masayasu S and Taeko K (1977). Simple colorimetric method for determination of serum triglycerides with lipoprotein lipase and glycerol dehydrogenase. Clinica Chimica Acta, 81: 125-130. Available at: https://www.sciencedirect.com/science/article/abs/pii/0009898177900031.

McDonald L (1980). Reproduction patterns of cattle. Veterinary Endocrinology and Reproduction. 3rd edition. Philadelphia: Lea and Febiger; PA., pp.377-396. Available at: https://www.cabdirect.org/cabdirect/abstract/19700102043.

Mellor D and Slatter J (1971). Daily changes in fetal fluids during last three months of pregnancy in conscious, unstressed ewes, with catheters in their foetal fluid sacs. The Journal of physiology, 217: 573-604. Available https://physoc.onlinelibrary.wiley.com/doi/abs/10.1113/jphysiol.1971.sp009587

Minazaki CK, Gagiotic S, Zago D, Terra W, Araujo VC, Oliveira RA and Bevilacqua E (2008). Acid phosphatase and cathepsin d are active expressed enzymes in the placenta of the cat. Research in veterinary Science, 84: 326-334. Available at: https://www.sciencedirect.com/science/article/abs/pii/S0034528807001713.

Moore K (1982). The developing human: Clinically oriented embryology. W. B. Saunders Co. Philadelphia. Available at: semanticscholar.org/6c4a/0cd45c9e7190f522bd6afdd68dbd762ad8dd.pdf.

Mufti A (1995). Studies on morphological characters and some metabolic constituents at different stages of development of ovine foetus [Thesis type]. Shalimar,Sprinagar: Sher-Kashmir University of agricultural sciences and Technology. Available at: http://www.skuastkashmir.ac.in/default.aspx.

Nauck M, Warnick GR and Rifai N (2002). Methods for measurement of ldl-cholesterol: A critical assessment of direct measurement by homogeneous assays versus calculation. Clinical chemistry, 48: 236-254. Available at: https://www.ncbi.nlm.nih.gov/pubmed/11805004

Nusbaum M and Zettner A (1973). The content of calcium, magnesium, copper, iron, sodium and potassium in amniotic fluid from eleven to nineteen weeks gestation. American Journal of Obstetrics \& Gynecology, 115: 219-226. Available at: https://www.ajog.org/article/0002-9378(73)902895 .

Oliveira F, Barros E and Magalhaes J (2002). Biochemical profile of amniotic fluid for the assessment of fetal and renal development. Brazilian Journal of Medical and Biological Research, 35: 215-222. Available at: http://www.scielo.br/scielo.php?pid=S0100-879X2002000200010.

Ozegbe P (2005). Comparative biochemical assessment of the amniotic fluid and maternal plasma of pregnant rabbits. Veterinarski arhiv, 75 (5): 431 437. Available at: https://hrcak.srce.hr/31916

Ozpinodotnar A and Finodotrat A (2003). Metabolic profile of pre-pregnancy, pregnancy and early lactation in multiple lambing sakiz ewes. Annals of nutrition and metabolism, 47: 139-143. Available at: https://search.proquest.com/openview/87f9ffaf1aa217031fd4753252b3dd9b/1?pqorigsite $=$ gscholar\&cbl $=32607$.

Prestes N, Chalhoub M, Lopes M and Takahira R (2001). Amniocentesis and biochemical evaluation of amniotic fluid in ewes at 70 , 100 and 145 days of pregnancy. Small Ruminant Research, 39: 277-281. Available at: https://www.sciencedirect.com/science/article/abs/pii/S0921448800002029.

Reddy AP, Reddy VSC, Rao GP, Sharma GVN, Reddy TJ, and Reddy VS (1995). Biochemical studies in the ewe (ovis aries) amniotic fluid during different phases of gestation. Indian Journal Animal Science, 10: 321-323. Available at: http://epubs.icar.org.in/ejournal/index.php/IJAnS/index.

Richardson CI, Jones PC, Bernard V, Hebert CN, TerlecKi S, and Wijeratne WV (1990). Estimation of the developmental age of the bovine fetus and newborn calf. The Veterinary Record,126: 279-284.Aailable at: https://europepmc.org/article/med/2343510.

Robert S (1986). Veterinary obstetrics and genital diseases. 3rd Edition. Wood Stock. pp: 41-49. Available at: https://ci.nii.ac.jp/naid/10027388121.

Robillard J, Nakamura K and Matherne G (1988). Renal hemodynamics and function adjustments to postnatal life. Seminar in perinatology, 12: 143150. Available at: http://www.scielo.br/scielo.php?pid=S0100-879X2002000200010\&script=sci_arttext.

Satlin L (1991). Maturation of renal potassium transport. Pediatric Nephrology, 5 (2): 260-269. Available at: https://link.springer.com/article/10.1007/BF01095968.

Sutcliffe R and Brock D (1973). Immunological studies on the nature and origin of the major proteins in amniotic fluid. Journal of obstetrics and gynaecology of the British Commonwealth, 80: 721. Availale at: https://academic.oup.com/humrep/article-abstract/4/1/99/608784.

Tabatabaei S (2012). Gestation variation in the biochemical composition of the fetal fluids and maternal blood serum in goat. Comparative Clinical Pathology, 21: 1305-1312.Available at: https://link.springer.com/article/10.1007/s00580-011-1286-4.

Tabatabaei S and Mamoei M (2012). Changes in the biochemical composition of fetal fluids and maternal blood serum during different days of gestation in cattle. Comparative Clinical Pathology,21: 1005-1012. Available at: https://link.springer.com/article/10.1007/s00580-011-1217-4.

Tamhane A and Dunlop D (2000). Statistics and Data Analysis: From Elementary to Intermediate. New York: Prentice-Hall. Available at: https://www.amazon.com/Statistics-Data-Analysis-Elementary-Intermediate/dp/0137444265.

Tietz NW (1995). Clinical Guide to Laboratory tests. 3rd edition. Philadelphia. WB. Saunders, 268-273. Available at: http://www.sciepub.com/reference/141231.

Tong X, Wang L, Gao L, Qin T, Qi Y and Xu Y (2009). Potential function of amniotic fluid in fetal development-novel insights by comparing the composition of human amniotic fluid with umbilical cord and maternal serum at mid and late gestation. Journal of the Chinese Medical Association, 72 (7): 368-373. Available at: https://www.sciencedirect.com/science/article/pii/S1726490109703892.

Underwood MA, Gilbert WM and Sherman MP (2005). Amniotic fluid: Not just fetal urine anymore. Journal of perinatology, 25 (5): $341-348$. Available at: https://www.nature.com/articles/7211290.

Wales R and Murdoch R (1973). Changes in the composition of sheep fetal fluids during early pregnancy. journal reproduction fertility, 33 : 197-205. Available at: https://rep.bioscientifica.com/view/journals/rep/33/2/jrf_33_2_002.

Williams MA, Wallace SS, Tyler JW, McCall CA, Gutierrez A and Spano JS (1993). Biochemical characteristics of amniotic and allantoic fluid in late gestational mares. Theriogenology, 40: 1251-1257. Available.at: https://www.sciencedirect.com/science/article/abs/pii/0093691X9390295.

Wintour E, Laurence B and Lingwood B (1986). Anatomy, physiology and pathology of the amniotic and allantoic compartments in the sheep and cow. Australian Veterinary Journal, 63: 216-221. Available at: https://onlinelibrary.wiley.com/doi/abs/10.1111/j.1751-0813.1986.tb02999.

Zanella L, Takahira R, Ona C, Magalhaes L and Prestes N (2014). Biochemical profile of amniotic and allantoic fluid during different gestational phases in mares. Journal of Equine Veterinary science,, 34: 403-406. Available at: https://www.sciencedirect.com/science/article/pii/S0737080613004772.

Zare-Bidaki M, Sadrinia S, Erhari S, Afkar E and Ghanbarzade N (2017). Antimicrobial properties of amniotic and chorionic membranes: A comparative study of two human fetal sac. Journal of Reproduction and Infertility, 2 (18): 218-224. Available at: https://www.ncbi.nlm.nih.gov/pmc/articles/PMC5565909. 